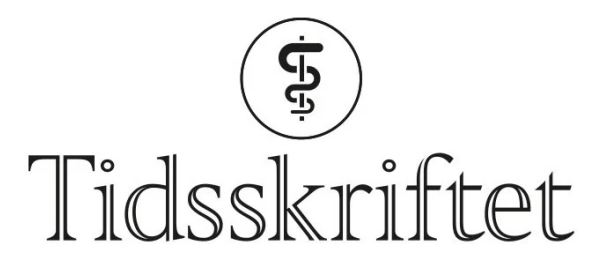

DEN NORSKE LEGEFORENING

\title{
Bare spør!
}

FRA REDAKTØREN

CHARLOTTE HAUG

redaktør

\section{Når fortrolige pasientopplysninger skal publiseres, må pasienten gi samtykke - også når informasjonen ikke er innhentet i forskningsøyemed}

\author{
"iा The health of my patient will be my first \\ consideration»» «Genèveerklceringen, Verdens legeforening 1949 (1)»
}

Utviklingen av medisinsk kunnskap fordrer tilgang til fortrolige pasientopplysninger enten gjennom enkeltobservasjoner eller gjennom systematiske kliniske studier. Laboratorieforskning og dyrefors $ø$ gir viktige bidrag til forståelsen av faget, men må alltid bekreftes i kliniske forsøk før de kan komme til anvendelse. Det kan fremstå som et dilemma for legen som behandler og forsker: Man har først og fremst ansvar for behandling av pasienten og taushetsplikt om det man får vite. Samtidig har man et ansvar for å videreformidle ny kunnskap til beste for andre pasienter og for samfunnet.

Medisinsk forskning må reguleres, og Sigmund Simonsen \& Magne Nylenna beskrev i en kronikk i Tidsskriftet i 2004 hvorfor og hvordan (2). De minnet om at leprabasillens oppdager, Gerhard Henrik Armauer Hansen (1841-1912), ble fradømt sin stilling fordi han podet materiale fra en spedalsk knute inn i øyet på en pasient uten hennes samtykke. Dette eksperimentet var avgjørende for å få undersøkt hvordan lepra smittet og var dermed til stor nytte for fremtidige pasienter, men retten fant likevel at Armauer Hansens handling både som lege og forsker var uakseptabel. Selv om denne rettsavgjørelsen står i en særstilling, illustrerer den likevel at samfunnet forventer spesiell etisk bevissthet og årvåkenhet av legen både som behandler og forsker. Det gjør også legene selv: Primo non nocere - først og fremst ikke skade - eller som det heter i Genèveerklæringen som Verdens legeforening vedtok etter den annen verdenskrig: «The health of my patient will be my first consideration» (1).

Den annen verdenskrig og det påfølgende rettsoppgjøret i Nürnberg markerer likevel et tidsskille for legeetikk og forskningsetikk. Allerede i juli 1945 møttes leger fra 29 land for å diskutere grunnleggelse av en internasjonal legeforening (3). Bakgrunnen var naturligvis de dramatiske bruddene på god lege- og forskningsetikk som hadde skjedd i de tyske konsentrasjonsleirene. Målsettingen var å få på plass et felles etikkregelverk som kunne 
forhindre liknende hendelser i fremtiden. Nürnbergkodeksen (4.) for forsvarlig medisinsk forskning ble formulert i forbindelse med rettsoppgjøret i 1947. Her står det informerte samtykket helt sentralt. To år senere vedtok Verdens legeforening Genèveerklæringen (1 1 ), som på mange måter er en moderne utgave av den hippokratiske ed. Dette var imidlertid ikke tilstrekkelig til å forhindre etiske overtramp, og i 1964 utformet Verdens legeforening Helsinkideklarasjonen (5, 6 ). Deklarasjonen har gjennomgått flere og store revisjoner, siste gang i $2008(7, \underline{8})$. Mens Nürnbergkodeksen omhandler forskning på friske mennesker, retter Helsinkideklarasjonen seg også mot klinisk forskning og forholdet mellom forskning og behandling av pasienter.

Dagens utgave av deklarasjonen er omfattende og streng. I tillegg kommer nasjonale lover og retningslinjer som også er kompliserte. En rekke hensyn og interesser skal ivaretas. I Norge fikk vi en ny helseforskningslov i 2008 (9). Tidsskriftets tidligere redaktør Magne Nylenna var sentral i utarbeidingen av loven. Et av formålene var forenkling av regelverket slik at ikke regelverket i seg selv skulle være til hinder for utviklingen av ny kunnskap (므). Likevel oppfatter mange leger og forskere det som unødig tungvint og byråkratisk å sette i gang forskningsprosjekter når både etisk forhåndsvurdering og vitenskapelig metodikk er gjort til lovpålagte krav i helseforskningsloven. Et alternativ er da å definere det man gjør som kvalitetssikring. Gjennomføring av intern kvalitetssikring er ønskelig og nødvendig i all medisinsk virksomhet - og det kan igangsettes uten godkjenning av etiske komiteer og uten samtykke fra pasientene (9.). Men hvor skal grensen trekkes mellom kvalitetssikring og medisinsk og helsefaglig forskning? Finnes det noen slik grense? Dette diskuteres nå i de etiske komiteene og ved universitetene (10 $)$.

I Tidsskriftet ser vi en økende tendens til at leger sender inn artikler basert på kvalitetssikringsprosjekter. De er dermed enten ikke vurdert av regional etisk komité eller komiteen har definert dem som utenfor sitt område. Dette blir et problem ved publisering fordi Tidsskriftet, i likhet med andre tidsskrifter, må gjøre sine egne publiseringsetiske vurderinger. Også vi er bundet av Helsinkideklarasjonen. Vår vurdering er at dersom et prosjekt er intern kvalitetssikring, skal det forbli internt. Dersom det ønskes publisert, må det være fordi man mener at det er av generell interesse, altså generaliserbart, og da må det håndteres som forskning. Med andre ord: Dersom kvalitetsstudier skal publiseres, kreves i det minste godkjenning av personvernombud. Det enkleste er likevel å be pasienten om lov-altså innhente samtykke.

Vi ønsker ikke at forskere skal få unødig arbeid, men ønsker heller ikke at de skal få urealistiske forhåpninger. Vi kan ikke bare se bort fra «byråkratiet» rundt klinisk forskning. Helsinkideklarasjonen er streng og binder alle medlemmer av Verdens legeforening - og dermed de aller fleste norske leger. Ikke bare det: Norge og Norden har vært toneangivende i arbeidet med de etiske retningslinjene helt fra starten av. Povl Riis og Erik Enger var bl.a. avgjørende for den viktige revisjonen av deklarasjonen i $1975(7,11,12)$. Tidligere generalsekretær Harry Martin Svabø har ledet etikkomiteen i Verdens legeforening. Dette vervet har nåværende president i Legeforeningen Torunn Janbu fra mai 2010.

\section{LITTERATUR}

1. WMA International Code of Medical Ethics. Declaration of Geneva. www.wma.net/en/3opublications/1opolicies/c8/index.html (2.8.2010).

2. Simonsen S, Nylenna M. Regulering av medisinsk forskning - hvorfor og hvordan. Tidsskr Nor Lægeforen 2004; 124: 2133-6.

3. Janbu T. Internasjonalt samarbeid om felles verdier. Tidsskr Nor Legeforen 2009; 129: 2683.

4. National Institutes of Health. Nuremberg code. http://ohsr.od.nih.gov/guidelines/nuremberg.html (2.8.2010).

5. Førde R. Helsinkideklarasjonen. www.etikkom.no/no/FBIB/Praktisk/Lover-ogretningslinjer/Helsinkideklarasjonen/ (2.8.2010). 
6. WMA. Declaration of Helsinki. Human experimentation - Code of ethics of the World Medical Association. www.ncbi.nlm.nih.gov/pmc/articles/PMC1816102/pdf/brmedj02559\%2Doo71.pdf (2.8.2010).

7. Aarseth HP. Helsinkideklarasjonen i ny utgave. Tidsskr Nor Lægeforen 2000; 120:3214.

8. WMA Declaration of Helsinki. Ethical principles for medical research involving human subjects. www.wma.net/en/3opublications/1opolicies/b3/index.html (2.8.2010)

9. Lov 2008-o6-20 nr. 44. Lov om medisinsk og helsefaglig forskning (helseforskningsloven). www.lovdata.no/all/hl-2008o620-044.html (2.8.2010).

10. Utne PH, Thelle D. Kvalitetssikring eller forskning? Tidsskr Nor Legeforen 2009; 129: 2385.

11. Riis P. Publikationsetik - om at formidle videnskab forståeligt og troværdigt. Tidsskr Nor Legeforen 2010; 130: 1359-61.

12. Feiring E. Høvdingen. Tidsskr Nor Legeforen 2010; 130: 1370-1.

Publisert: 12. august 2010. Tidsskr Nor Legeforen. DOI: 10.4045/tidsskr.10.15E1

(C) Tidsskrift for Den norske legeforening 2023. Lastet ned fra tidsskriftet.no 26. april 2023. 